\title{
From E-learning to Blended Learning: Re-designing Content and Frame in a Capacity Building Project
}

\author{
http://dx.doi.org/10.3991/ijet.v8i5.3001
}

\author{
Line Skov Hansen and Ole Hansen \\ Aalborg University, Aalborg, Denmark
}

\begin{abstract}
This paper presents the didactical considerations, theoretical approaches and first experiences with a cohesive school and kindergarten research-based development project in a Norwegian municipality. The project involves 41 schools and 70 kindergartens, inclusive all leaders and pedagogical staff. The project uses a "capacity building" strategy where new practice and skills are built through pedagogical interventions mostly designed as courses based on blended learning with a dialogue oriented and practice related teamwork as an important part. Through this work the team learns how to use a specific model for pedagogical analysis. By this model the team gets the opportunity to contribute and to collaborate on tasks related to their own practice. From our experience and from the qualitative research in a similar project in Denmark, with more than 500 schools and 29400 teachers, we know that these teams and thereby also the team facilitator play a very important role in the implementation of the new ideas and practices. Research from the Danish project also shows that both the content and frame in especially the course for team facilitators need a redesign.
\end{abstract}

Index Terms-capacity building, blended learning, evidence-informed practice, team-based learning, praxis related learning, cohesive school and kindergarten development.

\section{INTRODUCTION}

Today in Scandinavia there is a focus on both kindergartens and schools as inclusive learning environments which are able to create the possibilities for development, learning and wellbeing for each student/child [4]. This has created a demand for systematic and widely accessible competency development and continuing education within pedagogical professions as this is one of the fastest and most effective means to elevate the quality of the schools and kindergartens [7] and furthermore evidence based knowledge that skilled leaders and teachers are a crucial factor for well-functioning schools and kindergartens [10] [15], [16].

One main inspiration to this increasing focus on educational development has been the large school development project carried out in the Canadian province of Ontario in 2004-2011 [12]. In this successful development three keywords have been clear objectives: interaction between research, policy and practice and "capacity building" [18].

Inspired among others by the success of Ontario our work at Laboratory of Research Informed School Practice and Pedagogical Development (LSP), Aalborg University is both to establish the opportunities for this "capacity building" and to ensure the close interaction between research, policy and practice throughout all of our researchbased development projects with municipalities, schools, kindergartens and other educational organizations.

In practice this means that LSP has a "capacity building" approach to research-based development projects where practitioners, professional experts and researchers collaborate on producing evidence-based knowledge which all parties can benefit from. The aim is here to avoid the typical and traditional research-based development approach of endless pilot-projects which last as long as they are funded, and then disappear with no impact on the larger system [12]. Instead the aim in our projects is both to create new evidence-based knowledge and that LSP through partnerships based on common, measurable objectives and pedagogical interventions designed as competency development ensure that all involved partners and organizations work on an evidence-informed basis [9] and that new capacity which will improve practice and thereby the learning environment in schools and kindergartens is created.

\section{THE FLIK-PROJECT}

In Kristiansand, Norway LSP works with this "capacity building" approach in a newly established research-based development project called FLiK. FLiK stands for "Research-based Learning Environment Development in the Municipality of Kristiansand". The project runs from 2013 to 2016 and can be described as a cohesive school and kindergarten development project. The project involves all leaders (170) and pedagogical staff (2600) from 41 schools and 70 kindergartens. The project also involves collaboration with a local project team and the policy and municipal management level for schools and kindergartens. By including these different partners in the project the aim of LSP is to develop the entire established praxis around schools and kindergartens and thus obtain a better learning outcome for all children or students. This set up distinguishes the project from initiatives based on random and uncoordinated activities [12].

The overall aim of FLiK is to increase inclusion, learning achievements and possibilities for all children/students by focusing on the development of the learning environment in both school and kindergartens. These aims are operationalized into the following common objectives for each school or kindergarten community:

1) good relations between the participants (adults children/students)

2) inclusion of all children/students 
3) evidence-based knowledge about pedagogical practice and its impact on children's/students outcomes

4) a creation of professional cultures based on learning communities

5) a systematic collaboration between all the pedagogical professional adults about knowledge building

6) a strong pedagogical and learning-oriented leadership based on a management

The project is primarily collaboration between the $\mathrm{Mu}-$ nicipality of Kristiansand and LSP. The project is as described earlier led by a local project team with close connection to LSP. This collaboration means that both design and completion of the project are done in a strong collaboration between research and practice. The aim of this collaboration is also to ensure the anchoring of the project on a prospective basis. In connection to this partnership a group of external Nordic researchers are connected. Norway: Center of the Study of Educational Practice (SePU), Hedmark University College and University of Agder, Kristiansand. Sweden: Borås University College. Denmark: Centre for Strategic Research in Education (CSER), Aarhus University.

\section{RESEARCH DESIGN}

The research connected to the project is based on a mixed methods approach which consists of both quantitative and qualitative research methods. The quantitative part of the research is a digital survey where children from 4-5 years old, students, teachers, leaders and parents answer questions about behavior, subject-matters status, relationships, the physical environment of the school/kindergarten etc. This survey research is implemented two times in the project; in the beginning (T1) and in the end of the project (T2).

The intention of the quantitative research is to be able to identify and follow the effects of the project interventions both in each class or kindergarten group as well as with the staff and the parents. By a mapping portal both partners from research and practice are able to see for themselves which initiatives are working and why and how they are working and if the overall initiative has an effect. Through this the activities of FLiK are not only a professional school/kindergarten development laboratory, but also a research laboratory and a praxis laboratory [7].

The qualitative research part consists both of selected case studies and focus interviews with representatives from the pedagogical staff in both school and kindergarten. The intention of the qualitative studies is both to focus on selected themes identified by the first survey research (T1) and to understand how school- and kindergarten teachers experience the changes of the project. Furthermore to see if new pedagogical strategies have been developed in the school or kindergarten, if collaboration has qualitatively improved in addition to evaluating if the competency development through e-learning or blended learning has been beneficial.

The FLiK-project is currently at its very beginning. We have made the overall design and we currently run pilotcourses for team facilitators and for the pedagogical staff from about nine kindergartens and one school. We therefore point out that this paper is based on our experiences and not yet on research results from the project.

\section{CAPACITY BUILDING IN FLIK}

\section{A. A research-based development project}

In FLiK the institutional capacity and skills are built through pedagogical interventions based on different sorts of competency development for both leaders and their pedagogical staff. All the different interventions involve evidence-based knowledge among others results from both the qualitative and quantitative research (T1 and T) of the project. In many of the didactic designs of these interventions we use blended learning. Blended learning is a relatively new concept originating in the US and can in its broadest sense be defined as "the integration of thoughtfully selected and complementary face-to-face and online approaches and technologies" [5].

Another important element in the design is that the different pedagogical interventions are team-based, practiceoriented and that they are based on a problem-oriented approach to learning. Through a problem-oriented pedagogy the aim is to promote both community and selforganization [11].

As part of the "capacity building" approach in LSP it is an ambition that both evidence-based knowledge from other relevant research-projects/topics and the results from the quantitative and the qualitative research activities connected to the project are used to create a more evidenceinformed practice for all leaders and pedagogical staff in schools and kindergarten. The aim is here to build up practice on 'what research already shows work' and where impact from own practice as well is shown in different ways [8], [9]. A big challenge though is to how an evidence-informed practice is actually created as it is not sure at all that new knowledge is automatically translated into the school or kindergarten [3].

Another challenge is to ensure that both frames and content for the competency development of the pedagogical professions are working towards finding new methods and ways of organizing the professional "capacity building" of the project which ensures transfer between education and work [21].

In the didactic design of the pedagogical interventions connected to FLiK we bring both our own experiences running the biggest research-based school development project in Denmark, with more than 500 schools and 29400 teachers and results from the qualitative research connected to this [1], [2]. The Danish project involved among others different designs of team-based competency development based on e-learning or blended learning [6].

\section{B. Learning environment and pedagogical analysis}

In FLiK an important way to improve the learning environment in schools and kindergartens is through the development of a professional praxis for all pedagogical staff which is based on evidence-based reflection and pedagogical analysis. The aim of this practice is to create an increased understanding for the challenges in the learning environment without prescribing practice [12], [3], [8]. As a tool for this analytic practice the Municipality of Kristiansand has in connection with the FLiK-project chosen to implement a specific "model for pedagogical analysis", developed by the Norwegian professor Thomas Nordahl. This model is system-theoretical and has to be used systematically over time [14]. In FLiK the ongoing work with implementing the model into the praxis of schools or kin- 
dergartens will take 3 years. Emphasis is on the pedagogical staff's focus on the interaction between the student/child and the surroundings including looking critically at own teaching/pedagogical methods and class/group leadership [13].

The idea of using this model for pedagogical analysis is to create a stronger analytical and methodological basis and readiness for the pedagogical staff in their daily work in kindergarten or at school. The aim is here to achieve explicit understanding of the factors which release, influence and maintain wellbeing, behavioral, and learning problems in schools or kindergartens [13]. While working with the model the pedagogical staff is organized in teams with one team facilitator and 5-6 team members. In the team the team facilitator and the team members are in collaboration trying to understand and to solve challenges which they experience in the learning environment of the school or kindergarten. By this the pedagogical staff has an opportunity to contribute and to collaborate on tasks related to their own practice [2]. Through this the intention is to create a base for the pedagogical staff on which they together develop a terminology for pedagogical reflection, analysis and dialogue, collaboration and knowledge sharing at their school or kindergarten [1], [3], [13].

From our experience and from the qualitative research in the Danish project, we know that these teams and thereby also the team facilitator play a very important role in the implementation of the new ideas and practices which working with the model for pedagogical analysis demands [1].

\section{The Virtual Platform}

In the Danish project we used a virtual platform with both a project website and e-learning spaces. This virtual platform was designed for the purpose in collaboration with a Danish software company. This platform can be described as a LMS System with very few possibilities for interaction and communication between the different participants. From this project it is our experience that the participants only use the e-learning spaces as long as the course was running. The participants had in this platform very limited possibilities for action - the opportunities were here to pick up tasks or deliver written assignments, to find additional resources or post a comment on a notice board [6]. In FLiK we wanted to create a virtual platform which should not only be for the time being of a course, but which should be an important and more dynamic virtual frame to support the overall "capacity building" strategy of project.

As a consequence we have taken a different platform approach in FLiK. Instead of developing our own we "moved" into an established platform, which is already in use in the schools of Kristiansand and thereby known by all teachers and school leaders. This platform is called "itslearning" and is a Learning Management System (LMS) used by many schools and institutions of education worldwide. We have not chosen this virtual platform because it is the best, but because it has many of the functionalities we need and because it is a platform used by some of the participants already. By this choice we support the Municipality and its ambition to use "itslearning" in all the schools and to introduce it to the staff of the kindergartens of Kristiansand. By this choice our technical partners changed from an external software development company to a local pedagogical ICT-consultant.

\section{E-learning spaces}

In "itslearning" we have created e-learning spaces for our different pedagogical interventions and thereby also our and the local project team's collaboration with leaders, team facilitators and pedagogical staff in schools and kindergartens. These different e-learning spaces consist of different tasks for the competency development, tools, evidenced-based literature amongst others, videos etc. The ambition is that these e-learning spaces will be dynamic and that they will be an important platform for the communication and collaboration between researchers, professional experts and practice throughout the project. In the long term the intention is that these spaces will in the long term be taken over by the local project team which will use them in the facilitation of different networks connected to the project and for the anchoring of the project on a prospective basis.

In "itslearning" there's a possibility for all participants to communicate through an internal mail system. Messages here as well as new tasks in the e-learning space can be advertised in the private mailbox of the participants outside the LMS. "itslearning" also gives the possibilities for the participants to create and to work in their own documents or workspaces which can be shared with others. With these functionalities "itslearning" gives opportunities for the participants to create more Personal Learning Environments (PLE).

\section{E. Team based and practice related learning}

The first step for the team is a team based mandatory course based on blended learning. First of all the participants are introduced to new knowledge through an educational evening or afternoon at the workplace, including a pedagogical lecture and work with cases in teams. During this session, the participants are learning about the FLiKproject, the model of pedagogical analysis and the theoretical and empirical knowledge behind it. The course is run by the local project team and local experts which themselves have been through a competency development regarding how to be an advisor in connection to the model of pedagogical analysis and its team based, systemtheoretical approach.

After this session a period of 2-3 months follows where all pedagogical staff is participating in an e-learning session in teams. This session - equaling approximately 8 hours of work is planned as 4 modules. In all modules the assignments are problem-oriented and related to the pedagogical praxis which the team collaboratively will be developing for their own organization. Through the written assignments of each module the team works on analyzing needs for changes locally and with implementation of newly created ways of working. Through working with these modules the participant's reflections are emphasized. These reflections are identified by being closely related to praxis and could be characterized as "reflectionover-praxis" [20]. Through the team's collaboration to resolve problems related to the e-learning modules and observations from daily life, the participants experiences are paired with subject-matter and pedagogical concepts. These activities are planned through questions and research-based literature especially to develop new realizations based on praxis. 
Through the entire period with both activities and elearning the team obtains knowledge and experience about the theories, methods and the material which the work with the model for pedagogical analysis is based upon. Through the phases of the model the team works more systematically than usual with pedagogical challenges related to the learning environment. These challenges are centered on removing or reducing sustaining factors which limit the child/students possibilities for learning, development and wellbeing. By the phases of the model the team is "helped" to go straight into action. Instead, they are through working with the model and its phases jointly in an investigating and clarifying field, where they gather information, make analyzes and select actions [13]. The intention of this team based collaboration is to support the collective capacity of the pedagogical staff and their responsibility and capability to design, develop, inquire into, and implement good pedagogical practices [8], [17] and by this "capacity building" to eliminate factors in the learning environment that sustains exclusion, maintains lack of well-being and achievements for each child/student.

\section{RE-DESIGNING THE COURSE FOR TEAM FACILITATORS}

\section{A. The team facilitator}

The research on the implementation of the model for pedagogical analysis in Danish schools shows amongst other that a well-functioning team can have a direct impact on how factors in the learning environment that triggers can be solved. We also know from this research that the team facilitator plays a very important role [1]. A wellfunctioning team facilitator can help to boost the result of the co-operation beyond the level that each individual could have attained and can by facilitating the process using the model properly ensure that the team work generate new knowledge which can open up new opportunities for bringing resolutions to many of the challenges of each school or kindergarten [1], [2]. A competent team facilitator can both help the team to identify best practices and to develop next practices which will sometimes turn out to be the best practices of the future [8]. In this work the team facilitator must:

- ensure that the phases of the model pedagogical analysis are followed systematically

- structure and manage the meeting with a progression in the work - in a positive atmosphere

- review agenda and put the work in progress

- ensure that the work will result in concrete proposals for action

- summarize decisions and ensure a common understanding of the sustaining factors and measures

- put evaluation and possible reviewing on the group's agenda

- ensure that the work of the team is based on evidence-based knowledge

- [1], [13].

It is of very big importance that the function as a team facilitator is well supported and that the course for competency development meets the needs of the tasks which the team facilitator has in supporting the learning- and work- ing together of the team members. As a preparation for this the team facilitator gets an additional competency development in connection with the one all pedagogical staff participate in. In the Danish project the competency development of the team facilitator consisted of four elearning modules which each took about two hours to solve. The team facilitators at each school or kindergarten here worked together on the written assignment connected to each module. They got supported by an external advisor who gave them response on their assignments. In the Danish project this course was run in the same period as the entire pedagogical staff got their course. This meant that the Danish team facilitators started their work in the team without being educated in advance.

From the qualitative research in the Danish project, based on focus group interviews on 112 schools in 2009 we know that:

- it can be frustrating to begin the role as a team facilitator without having finished the course for team facilitators in advance

- it can be felt as a heavy responsibility to be a team facilitator

- it can be a dilemma to have a leadership function related to colleagues

- to be a team facilitator can be a lonely job

- a larger focus on the role as team facilitator, the frame and content of the competency development and the support afterwards is recommended

- after the four e-learning modules the team facilitators do not always feel prepared for their role

- additional competency development is a wish from many team facilitators [1]

Based on these qualitative research-results we have decided to re-design the competency development for team facilitators in the FLiK-project. In practice this means that we in FLiK first of all has gone from a design using only e-learning to a design based on blended learning. The FLiK-project is as mentioned earlier still in its very beginning and we have so far designed a pilot-course which has run twice with among 70 participants from both schools and kindergartens. By making a pilot as the first step to a re-design we have had a chance to make a more participatory design and to improve our frame and content as we go along. This approach can be described as iterative design process [19], where improvements, changes and new developments have been made with inspiration from needs, experiences, and wishes from participants.

\section{B. Face to face seminars}

In our re-design for the competency development of team facilitators we have decided to run this course before the course for all pedagogical staff. By this the team facilitator gets a chance to be prepared in advance for the role. As for re-designing the frames and content of the course for team facilitators in FLiK we first of all wanted to meet the team-facilitators in person and to create a possibility for the team facilitators to meet each other as well. In FLiK we have made a design with two face to face seminars and only two e-learning modules. The face to face seminars are run by LSP and are in the beginning and in the end of the course. In the content of the face to face seminars we put strong emphasis on theories about adult learning, innovational change and team work. These face 
to face meetings are organized as a mixture between lectures, discussions and team work. The discussions and the team work are organized so the team facilitators from different schools get an opportunity to collaborate and share knowledge across their daily work and institutions.

By this organization we want to support the creation of a network for team facilitators which can continue with the help form the local project team after the ended competency development. This network is also thought as a way forward to create a professional forum for the team facilitators and to support the capacity strategy of the overall project which includes an evidence-informed practice of the team, which among other means the use of current evidence-based knowledge from the results of the quantitative and qualitative research connected to the project.

\section{The e-learning space for team facilitators}

In the e-learning space for team facilitators each team gets the tasks connected to the two modules and delivers their written assignments to an advisor from LSP which gives them feedback on their written work. The two modules both consist of literature and tasks about communication theory, question types and the use of model for pedagogical analysis. In this e-learning space both researchers and the local project coordinators can support learning with different modalities as texts, pictures, video etc. As the space is owned by the Municipality the aim is to use the space beyond the e-learning period in connection with the network for team facilitators. The internal mail system in "itslearning" makes it possible for the participants to communicate with the representatives from LSP, the local project team or each other.

\section{SUMMARY AND CONCLUSION}

In this article we have first of all described the overall "capacity building" strategy which LSP uses in the FLiKproject amongst others. This strategy includes:

- evidence-informed capacity building and cohesive development in kindergartens and schools

- use of blended learning based on practice related team work

- close collaboration between research and practice

- close collaboration with a local project team

- a strong focus on how to ensure translation of the evidence-based knowledge which is created in the project

- a strong focus on how to ensure that what is offered through the pedagogical interventions has value related to the practice that needs to be developed in the participating schools and kindergartens

- continuous evaluation and continuous update on content in both e-learning space, e-learning modules and face to face seminars

So far we have got the first experiences with our pilotcourses for team facilitators. Evaluation based on written comments in groups made at the face to face seminars for team facilitators, shows that especially these seminars and their mixture of discussions and working with cases across each individual institution has been a success. The written assignments related to the e-learning modules also show both a high engagement and ownership to the role as team facilitator.

As for the use of "itslearning" as our virtual platform we have experienced so far that the internal communication system is used by the team facilitators to communicate with LSP in relation to the e-learning modules or with questions in relation to the use of the model. As a LMS "itslearning" has so far shown to be easy to use though there is also some minor challenges as its functions are not designed especially to FLiK and its blended learning. We must though conclude that these challenges are not bigger than they can be solved in collaboration with the local pedagogical ICT consultant and the local project team. We can also conclude that to "move" into an unknown platform demands quite a lot of technical qualifications and experiences from us (LSP) as designers and responsible for the realizations of the pedagogical interventions connected to the FLiK-project.

\section{ACKNOWLEDGMENT}

The authors want to thank the local FLiK-team in Kristiansand, Norway; Øivind Jacobsen, Marianne Godtfredsen and Bente Nyborg for collaboration and inspiration in our shared work with the project.

\section{REFERENCES}

[1] Andresen, B. B. (2010): "Skoler i udvikling: undersøgelse af brugen af LP-modellen". Frederikshavn: Forlaget Dafolo

[2] Andresen, B. (2012): Det ved vi om - pædagogisk analyse og kompetenceudvikling. Frederikshavn: Forlaget Dafolo

[3] City, E. A; Elmore, R. F.; Fairman, S. E. \& Teitel, L. (2010): Instructional rounds in education - a network approach to improve teaching and learning. Cambrigde, Massachuset: Harvard Educational Press

[4] Egelund, N., Haug, P. \& Persson, B. (2006): Inkluderende pedagogik i skandinavisk perspektiv. Stockholm. Liber

[5] Garrison, D. R., \& Vaughan, N. (2008). "Blended learning in higher education”. San Francisco: Jossey-Bass, p. 148.

[6] Hansen, L. S.; Hansen, O. \& Andersen, P. G. (2012): E-learning and Comprehensive School and Kindergarten Development. International Journal of Advanced Corporate Learning, volume 5, Issue 3, pp. 13-17.

[7] Hansen, O. \& Qvortrup L. (2011): "Vejen til en bedre skole". Chronicle in Politikken the 2th. June 2011 http://politiken.dk/ debat/kroniker/ECE1297869/vejen-tilen-bedre skole/

[8] Hargreaves, A. \& Fullan, M. (2012): Professional Capital - transforming teaching in every school. New York.

[9] Hattie, John (2011): Visible Learning for teachers. London and New York. Routledge.

[10] Hattie, John (2009): Visible Learning. A Synthesis of over 800 Meta-Analyses Relating to Achievement. Routledge: London and New York.

[11] [Jank, W. \& Meyer, H. (2009): "Didaktiske modeller" Copenhagen. Gyldendal.

[12] Levin, Ben (2010): How to Change 5000 Schools. A Practical and Positive Approach for Leading Change at Every Level. Cambridge MA: Harvard Education Press

[13] Nordahl, T. (2011): "Arbejdet med LP-modellen: beskrivelse af analysemodellen og strategier for implementering i skolen". This booklet is the basic literature for the e-learning modules connected to the introduction of the model in Denmark.

[14] Nordahl. T (2012): Dette vet vi om - pedagogisk analyse. Norsk Gyldendal

[15] Nordenbo, S. E; Søgaard Larsen, M; Tiftikçi, N; Wendt, R. E. \& Østergaard, S. (2008): "Lærerkompetencer og elevers læring i førskole og skole - Et systematisk review udført for Kunnskapsdepartementet, Oslo. http://dpu.dk/Everest/Publications/udgivelser\%5 Cclearinghouse/20080508105700/CurrentVersion/Systematisk 
\%20review $\% 202 \% 201 \% \mathrm{C} 3 \%$ A6rerkompetencer.pdf?RequestRepa ired $=$ true

[16] OECD (2006): Starting Strong II: Early childhood education and care. Paris: OECD Publications. http://www.oecd.org/document/ 63/0,3746,en $26493926323137416703 \quad 1 \quad 1 \quad 1 \quad 1,00$. html

[17] Persson, B. \& Persson, E. (2012): Inkludering och måluppfyllelse : att nå framgång med alla elever. Stockholm: Liber

[18] Qvortrup, L.; Rasmussen, J. \& Staunæs D.(2012): Visionen for den nye, stærke danske skole, Chronicle in Politikken the 9th. February 2012

[19] Rogers, Preece \& Sharp (2007): "Interaction design: beyond human-computer interaction”, 2. ed., West Sussex: John Wiley \& sons, Ltd, chap. 9.

[20] Schön, Donald A. (2001): "Den reflekterende praktiker. Hvordan professionelle tænker, når de arbejder". Aarhus: Forlaget Klim

[21] Wahlgren, B. (2009): "Transfer mellem uddannelse og arbejde". Copenhagen: Nationalt Center for Kompetenceudvikling.

\section{AUTHORS}

Line Skov Hansen, Teacher, Master in ICT and Learning, and Master in Learning and Innovative Changes has worked as a project assistant at Centre for Knowledge-
Based Educational Practice, University College Nordjylland and is now research assistant at Laboratory of Research Informed School Practice and Pedagogical Development (LSP), Department of Learning and Philosophy, Aalborg University, Denmark (e-mail: 1sh@learning.aau.dk, website: www.lsp.aau.dk).

Ole Hansen, has been Chief Psychologist at Pedagogical Psychological Consultancy Office in the municipalities of Hadsten, Hinnerup and Rosenholm from 1976-2001, the Head of the Ministry of Educations "KVIS program" from 2001-2007, leader of Centre for Knowledge-Based Educational Practice and project manager at the LPmodel, University College Nordjylland from 2007-2011. $\mathrm{He}$ is now working at Laboratory of Research Informed School Practice and Pedagogical Development (LSP), Department of Learning and Philosophy, Aalborg University, Denmark (e-mail: oh@learning.aau.dk, website: www.lsp.aau.dk

Manuscript received 08 July 2013. Published as re-submitted by the authors 13 October 2013. 